\title{
D-23 UNDISCOVERED RESOURCES IN RIFT BASINS OF THE MEDITERRANEAN - COMPARISON TO THE NORTH SEA
}

DONALD L. GAUTIER, THOMAS S.J. AHLBRANDT and MARK PAWLEWICZ

U. S. Geological Survey, 345 Middlefield Road, Menlo Park CA 94025, USA

\begin{abstract}
Three prominent rift basins in the immediate vicinity of the Mediterranean Sea are identified as having significant petroleum potential: the Sirte Basin, the Red Sea Basin, and the Provence Basin. It is estimated that these three petroleum provinces contain undiscovered resources in excess of 126 trillion cubic feet of natural gas and 12 billion barrels of oil as well as abundant natural gas liquids. Onshore, Sirte Basin is at a statistical state of exploration maturity considerably less than that of the North Sea, and has significant additional resources in undrilled offshore areas. The Red Sea Basin, with undiscovered resources considerably in excess of cumulative production and proved reserves, is also in a condition of exploration maturity significantly less than the North Sea Graben. Provence Basin is a frontier area, with no history of production or proved reserves, but with considerable potential for natural gas in high-risk plays.
\end{abstract}

Reducing the large range of uncertainty associated with these estimates presents a significant challenge to the explorationist interested in the Mediterranean area. Because of its long history of exploration and production and because of the availability of abundant public data, the rift-related oil and gas accumulations of the North Sea can be an instructive analog for comparison. Although different in details of source rocks, reservoir rocks, and exploration history, the geologic concepts, field-size distributions, and future production in the North Sea provide many parallels for evaluation o potential discoveries and future reserve growth in rift basins of the Mediterranean.

In the Sirte Basin, in addition to potential for large quantities of undiscovered oil and gas in carbonate reservoirs onshore, undiscovered resources are expected in the offshore Gulf of Sirte in water depths to $2000 \mathrm{~m}$. As in the North Sea, potential traps exist in pre-rift, syn-rift, and post-rift settings. The expected undiscovered accumulations would probably be sourced in the Cretaceous Sirte Shale with reservoirs in Cretaceous siliciclastic rocks as well as in Cretaceous through Eocene carbonates and in various older rocks. Seals probably consist of evaporites in the Eocene Gir Formation. The burial depths and thermal regime of the Sirte Basin predict a predominance of gas relative to oil. Although the Sirte has been a highly productive basin onshore and great potential exists for offshore accumulations, extrusive rocks pose significant risk, as do complex structures related to shear zones and subduction to the northeast of the basin.

The Red Sea Basin has been only partially explored to date, and considerable potential exists for undiscovered resources. In contras to the North Sea or the Sirte Basin, rifting in the Red Sea began in the Oligocene and continues to the present. Source rocks for undiscovered resources are not confined to a single dominant carbon-rich shale such as the Kimmeridge of the North Sea, but rather may include various geographically limited syn-rift shales that have reached thermal maturity at times during the past $10 \mathrm{Ma}$. Reservoirs could include Miocene and younger sandstones and carbonates from various depositional environments. In the Salt Basin itself, trapping mechanisms can be either stratigraphic or structural, and are related to salt tectonics. Evaporites of Miocene and Pliocene age 
may provide a regional seal. On the margins of the Red Sea, tilted fault blocks of Oligocene and Miocene age are the principal localities of undiscovered accumulations.

In stark contrast to the well known and extensively explored North Sea Graben and the partially explored Sirte and Red Sea Basins, the Provence Basin is a rift basin in a frontier province about which little is known in detail. Both the potential for undiscovered resources and the risk of failure are great. Undiscovered resources may exist beyond the continental shelf and below the Miocene Messinian evaporites in the deep western Mediterranean. Possible source rocks include Upper Cretaceous through Oligocene marine shales, and Miocene sapropels. Crustal attenuation suggests that these shales are highly mature to overmature with respect to oil generation, and may be generating gas. Reservoir rocks are likely to be Oligocene and Miocene submarine fan and channel deposits, as well as Cretaceous carbonates. Structural controls may be exerted by salt diapirism, Messinian age evaporites probably serve as regional seals.

Considerable potential for undiscovered petroleum exists in rift basins of the Mediterranean region. The Mediterranean rift basins are in various states of exploration maturity ranging from well-explored onshore areas to rank frontier provinces about which little is known. Uncertainties and high exploration risk combined with a tendency toward high gas-to-oil ratios make many of these resource economically difficult. Nevertheless, upside potential for natural gas development will bring these areas to the forefront of exploration in the not-too-distant future. The North Sea Graben provides a useful comparison in evaluating these rift-related accumulations. 